\title{
Review
}

Journal of Innate

Immunity
J Innate Immun 2016;8:111-120

DOI: $10.1159 / 000443526$
Received: November 30, 2015

Accepted after revision: December 21, 2015

Published online: February 5, 2016

\section{Paul Ehrlich (1854-1915) and His \\ Contributions to the Foundation and Birth of Translational Medicine}

\author{
Peter Valent ${ }^{\mathrm{a}, \mathrm{b}}$ Bernd Groner ${ }^{\mathrm{c}}$ Udo Schumacher ${ }^{\mathrm{d}}$ Giulio Superti-Furga ${ }^{\mathrm{e}}$ \\ Meinrad Busslinger ${ }^{f}$ Robert Kralovics ${ }^{a}{ }^{\text {e }}$ Christoph Zielinskig Josef M. Penninger ${ }^{\text {h }}$ \\ Dontscho Kerjaschki ${ }^{i}$ Georg Stingl ${ }^{j} \quad$ Josef S. Smolen ${ }^{k}$ Rudolf Valental Hans Lassmann ${ }^{m}$

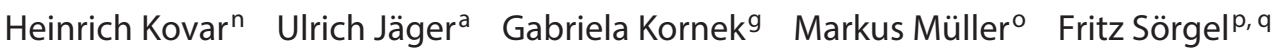 \\ a Department of Medicine I, Division of Hematology and Hemostaseology, Medical University of Vienna, \\ Vienna, Austria; ${ }^{b}$ Ludwig Boltzmann Cluster Oncology, Medical University of Vienna, Vienna, Austria; ${ }^{C}$ Institute for \\ Tumor Biology and Experimental Therapy; Frankfurt/Main, Germany; ${ }^{\mathrm{d} C e n t e r ~ f o r ~ E x p e r i m e n t a l ~ M e d i c i n e, ~ I n s t i t u t e ~}$ \\ for Anatomy and Experimental Morphology, Medical University of Hamburg, Hamburg, Germany; ${ }^{\text {CCenter for }}$ \\ Molecular Medicine (CeMM) of the Austrian Academy of Sciences, Vienna, Austria; ${ }^{f}$ Research Institute of Molecular \\ Pathology, Vienna, Austria; ${ }^{9}$ Department of Medicine I, Clinical Division of Oncology, Comprehensive Cancer Center \\ (CCC) Vienna, Medical University of Vienna, Vienna, Austria; ${ }^{h}$ Institute of Molecular Biotechnology (IMBA) of the \\ Austrian Academy of Sciences, Vienna, Austria; 'Department of Pathology, Medical University of Vienna, \\ Vienna, Austria; 'Department of Dermatology, Division of Immunology, Allergy, and Infectious Diseases, Medical \\ University of Vienna, Vienna, Austria; ${ }^{k}$ Department of Medicine III, Division of Rheumatology, Medical University \\ of Vienna, Vienna, Austria; 'Department of Pathophysiology and Allergy Research, Division of Immunopathology, \\ Medical University of Vienna, Vienna, Austria; ${ }^{\mathrm{m} C e n t e r}$ for Brain Research, Medical University of Vienna,

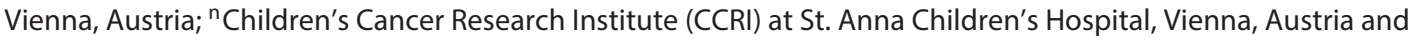 \\ Department of Pediatrics, Medical University, Vienna, Austria; ${ }^{\circ}$ Department of Clinical Pharmacology, Medical \\ University of Vienna, Vienna, Austria; ${ }^{\mathrm{P}}$ Institute for Biomedical and Pharmaceutical Research (IBMP), Nürnberg,

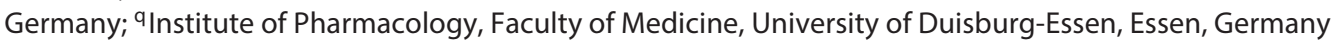

\section{Key Words}

Leukocyte typing $\cdot$ Immune effector cells $\cdot$ Receptor/ligand theory $\cdot$ Magic bullets $\cdot$ Salvarsan $\cdot$ Translational medicine

\footnotetext{
Abstract

Translational research and precision medicine are based on a profound knowledge of cellular and molecular mechanisms contributing to various physiologic processes and pathologic reactions in diverse organs. Whereas specific molecular interactions and mechanisms have been identified during the past 5 decades, the underlying principles were
}

defined much earlier and originate from to the seminal observations made by outstanding researchers between 1850 and 1915. One of the most outstanding exponents of these scientists is Paul Ehrlich. His work resulted not only in the foundation and birth of modern hematology and immunology, but also led to the development of chemotherapy and specific targeted treatment concepts. In 2015, the Medical University of Vienna organized a memorial meeting, with the

This manuscript is dedicated to the achievements of Paul Ehrlich on the occasion of the 100th anniversary of his death (August 20, 2015).

\section{KARGER}

E-Mail karger@karger.com www.karger.com/jin
Prof. Peter Valent

Department of Medicine I, Division of Hematology and Hemostaseology, and Ludwig Boltzmann Cluster Oncology

Medical University of Vienna, AT-1090 Vienna (Austria)

E-Mail peter.valent@meduniwien.ac.at 
aim of honoring Paul Ehrlich's contributions to science, and to commemorate the 100th anniversary of his death. The authors of the current review served as faculty members and dedicate this paper to Paul Ehrlich and his remarkable contributions to medicine.

(C) 2016 S. Karger AG, Basel

\section{Introduction}

Between 1850 and 1915, the 'young' scientific disciplines of chemistry, biology, physics and medicine made substantial progress based on the outstanding contributions of a growing number of ingenious scientists, including Louis Pasteur, Rudolf Virchow, Ilja Iljitsch Metschnikow, Carl von Rokitansky, Robert Koch, Karl Landsteiner, Emil von Behring, and others (table 1). Inspired by this atmosphere of pioneering discoveries and achievements, Paul Ehrlich emerged as one of the most famous and influential researchers at that time and as a cofounding pioneer of the fields of hematology, immunology, pharmacology and chemotherapy [1-3]. Early in his career Ehrlich was soon recognized as a talented chemist, and after leaving the Charité Hospital in 1885, where he had worked as a physician, Ehrlich became completely obsessed by laboratory research.

During his career, Ehrlich exploited his knowledge of chemistry and thereby was able to merge cellular and molecular theories into new concepts. Subsequently, he defined biological principles and demonstrated their practical implications and their applicability in medicine. By doing so, Paul Ehrlich established basic principles of translational medicine. These principles and hypotheses not only became tremendously useful, but many of his ideas also inspired and encouraged multiple generations of scientists to pursue such promising avenues, and are still instrumental to our thinking and designing in experimental and applied medicine today. One famous example is the side-chain theory that proposed the existence of distinct membrane-related structures that can interact with extracellular molecules (ligands) [4]. This theory was later extended to a generally applicable receptorligand concept that greatly influenced the fields of physiology, immunology, hematology and pharmacology, and is still fundamental in science today (table 2).

In the later phases of his career, Paul Ehrlich worked intensively in the fields of immunology, chemistry, pharmacology and antimicrobial chemotherapy, with the aim of developing target-specific approaches and related treatment concepts. Specifically, he postulated that spe- cific molecules exposed in microbial cells can serve as specific target structures, and that these interactions can be pharmacologically exploited to develop specific drug therapies and immunotherapies. This would become a global principle applicable to pathogenic microorganisms, but also to any other cell type, including cancer cells.

In a pioneering effort to detect drugs capable of specifically killing certain microbes, Ehrlich synthesized a series of specific antimicrobial drugs, the most famous example being arsphenamine (Salvarsan ${ }^{\circledR}$ ), the first synthetic agent against syphilis [5]. Due to the huge success of this drug, Ehrlich was able to popularize his new concept of a 'magic bullet' ('Zauberkugel'), a drug specifically targeting a particular pathogen without affecting normal host cells. Despite his many outstanding achievements in various disciplines, Paul Ehrlich's name undoubtedly remains very much linked to the development of Salvarsan ${ }^{\circledR}$ and the related birth of targeted therapies.

In the current article, we provide a short overview of Paul Ehrlich's life and career and a review of his major contributions to chemistry, hematology, immunology, pharmacology, drug development and translational medicine. Interested readers who would like to learn more about Paul Ehrlich's life and achievements are referred to the available literature and the online compilation of his publications $[3,6-10]$.

\section{A Short Overview of Paul Ehrlich's Life and Career}

Paul Ehrlich was born in Strehlen in Prussia, in the district of Silesa (now part of Poland) in March 1854. Already as a teenager, Paul was fascinated by the process of staining microscopic tissue sections his cousin Karl Weigert, a famous pathologist, prepared. Between 1872 and 1877, Paul Ehrlich studied medicine at the Universities of Breslau, Strassburg and Freiburg. In 1878, he obtained his doctoral degree in medicine in Leipzig. Although trained as a physician, Paul Ehrlich was obsessed by laboratory work and dye staining of tissue samples and blood leukocytes [10-13]. Paul Ehrlich's career can essentially be divided into three phases (table 3 ), all of which were influenced by his deep understanding of the principles of chemistry and the related idea of specific molecular interactions in various biological systems [14].

In the first phase of his career (1878-1890), Ehrlich developed the principles of modern hematology and immunology by describing various leukocyte subsets and their precursor cells. In addition, Ehrlich contributed to the field of microbiology and was involved in the classification of 
Table 1. Leading scientists working at the time of Paul Ehrlich (1870-1915)

\begin{tabular}{|c|c|c|}
\hline Scientist's name & Years & Major achievements or concepts \\
\hline Emil von Behring & $1845-1917$ & $\begin{array}{l}\text { Development of serum therapies and modern vaccination } \\
\text { medicine }\end{array}$ \\
\hline Marie Curie & $1867-1934$ & $\begin{array}{l}\text { Discovery of radium and polonium; described the concept of } \\
\text { radioactivity }\end{array}$ \\
\hline Pierre Curie & $1859-1906$ & Discovery of nuclear energy; pioneer in magnetism \\
\hline Hermann Emil Fischer & $1859-1919$ & $\begin{array}{l}\text { Purine and sugar chemistry; synthetic polypeptide chemistry; } \\
\text { discovery of barbiturates }\end{array}$ \\
\hline Sigmund Freud & $1856-1939$ & $\begin{array}{l}\text { Development of psychoanalysis; modern psychology and } \\
\text { psychiatry }\end{array}$ \\
\hline Robert Koch & $1843-1910$ & $\begin{array}{l}\text { Discovery of Mycobacterium tuberculosis; cofounder of the } \\
\text { field of microbiology }\end{array}$ \\
\hline Ilja Iljitsch Metschnikow & $1854-1916$ & $\begin{array}{l}\text { Discovery of a leukocyte-based natural host defense; } \\
\text { description of phagocytosis of bacteria }\end{array}$ \\
\hline Karl Landsteiner & $1868-1943$ & $\begin{array}{l}\text { Detection of A-B-O blood groups; development of the hapten } \\
\text { concept; detection of Rickettsia prowazekii }\end{array}$ \\
\hline Louis Pasteur & $1822-1895$ & $\begin{array}{l}\text { Detected the principles of vaccination; described microbial } \\
\text { fermentation; developed pasteurization }\end{array}$ \\
\hline Wilhelm Conrad Roentgen & $1845-1923$ & Discovery of X-rays; foundation of radiology \\
\hline Carl von Rokitansky & $1804-1878$ & $\begin{array}{l}\text { Development of anatomic pathology; introduced the issue of } \\
\text { humanity and ethics in medicine and research }\end{array}$ \\
\hline Rudolf Virchow & $1821-1902$ & $\begin{array}{l}\text { Postulated a cellular basis of disease; description of blood } \\
\text { cancer/leukemia; pathogenesis of vascular thrombosis }\end{array}$ \\
\hline
\end{tabular}

The table includes a short compilation of the most influential researchers working in the fields of medical sciences at the time of Paul Ehrlich, listed in alphabetical order.

diverse microbes. All these observations were essentially based on his unmatched talent to develop advanced dyestaining techniques and to adapt these techniques in improved form to various cell systems and organisms.

In the second phase of his career, Ehrlich developed new concepts connecting certain (dye-staining) cell properties with the expression of distinct (cell-specific) receptors and molecules. Specifically, Ehrlich developed his side-chain theory (1897) and subsequently a receptor-ligand concept (table 3 ). In these years, Ehrlich also worked hard in the field of passive immunotherapy. For example, he contributed greatly to the development of an effective antiserum against diphtheria and to the approach of producing standardized therapeutic serum-fractions [15]. The successful approach to standardizing biologically active substances was a great breakthrough that supported the development of immunotherapies, and also paved the way to standardized production of biologically active drugs in other fields of medicine.

In the third phase of his career, Paul Ehrlich made substantial attempts to translate his theoretical and practical findings into therapeutic concepts. Specifically, he tried to synthesize targeted drugs applicable to patients. After a long time of experimental work, preclinical studies in animal models, and many disappointments, Ehrlich was able to synthesize a first small series of successful synthetic drugs, the most famous example being Salvarsan ${ }^{\circledR}$ [5]. It was an enormous breakthrough and a triumph of synthetic drug development when Salvarsan ${ }^{\circledR}$ was introduced (1909). Ehrlich was convinced that many more drugs could be synthesized chemically and be directed specifically against microbes or even against cancer cells. However, in this phase of his career he also realized and studied certain limitations of therapy, such as drug resistance and toxicity. In all these studies and phases of his career, Ehrlich was able to exploit his vast knowledge about chemical principles for the development of new biological or therapeutic concepts [14].

Paul Ehrlich began his career while still a student at the University of Freiburg, when he first described specific dye-staining properties of various blood leukocytes and other cell types [11-13]. When observing that the uptake of different dyes varied in different cells and tissues, he concluded that specific affinities between biologic structures and the stain applied must exist. A milestone in the field of neurosciences was Ehrlich's observation that, af- 
Table 2. Paul Ehrlich's theories and concepts and their impact on the development of modern scientific disciplines

\begin{tabular}{ll}
\hline Theory/concept & Emerging/resulting disciplines \\
\hline $\begin{array}{l}\text { Differentiation of leukocytes by distinct } \\
\text { dye-staining properties }\end{array}$ & Blood counting and typing \\
& Modern hematology \\
\hline Standardization of biologically & Identification of immune cells \\
active antiserum & Delineation of blood cell disorders \\
& Serum protein research \\
\hline Side-chain theory & Standardized vaccination protocols \\
& Vaccination medicine \\
\hline Magic bullet theory ('Zauberkugel-Theorie') & Receptor-ligand concepts \\
& Immunoglobulin receptor research \\
& Modern immunology \\
& Immunopathology \\
\hline Development and application of specific drugs & Preclinical drug design and drug testing \\
& Development of targeted drugs \\
& Synthetic chemotherapy \\
& Target expression profiling \\
\hline & Clinical pharmacology and drug validation \\
& Modern clinical oncology and hematology \\
& Modern anti-infective drug therapies/modern \\
\end{tabular}

ter intravenous injection, water-soluble dyes stained most tissues with the exception of the brain and spinal cord, a discovery that paved the way to the identification of the blood-brain barrier. Ehrlich was soon recognized as an outstanding researcher and worked at the Charité in Berlin in association with Robert Koch. In 1896 he became the Director of the Institute for Serum Research and Evaluation in Berlin; in 1899 he was promoted to Director of the Institute for Experimental Therapy, and in 1906 became Director of the Georg-Speyer-Haus, Chemotherapeutic Research Institute, in Frankfurt (table 3).

During his career Paul Ehrlich received several honors and awards. His achievements were highlighted by 10 'Honorary Doctorates' and by the Prussian Great Gold Medal for Science in 1903. As Director of the GeorgSpeyer-Haus, Paul Ehrlich greatly intensified the production and testing of various chemical compounds; by doing so, he established the principles of chemotherapy, and finally he developed Salvarsan ${ }^{\circledR}$ in his institute. In 1908, Paul Ehrlich received the Nobel Prize in Physiology or Medicine together with Elie Metchnikoff for their work and basic insights into immunological defense mechanisms [7-9]. Both concepts were complementary and later formed the basis of humoral and cellular immunology. In particular, Ehrlich was propagating a 'molecular serum theory' and Metchnikoff a 'cell-phagocytosis theory'.
Despite of his discoveries and the awards and honors he received, Paul Ehrlich had to fight many battles against prejudice, jealousy and ignorance in his life. For example, he had to work hard to convince the scientific community as well as the public that his concepts and efforts were useful and that the resulting applications were beneficial for patients [4]. In 1912 and 1913, Ehrlich was again nominated for the Nobel Prize, this time for his contributions to chemotherapy [16]. It would have been an appropriate recognition for Salvarsan ${ }^{\circledR}$ as a first 'synthetic chemotherapy' (targeted drug). However, in those days, it was 'too early' for a synthesized targeted drug to be presented as a triumph of science to the community.

Paul Ehrlich was a great personality and a dedicated researcher. He was a straight and modest man with a good sense of humor, but was also an energetic and enthusiastic worker. As a perfectionist, he retested, requestioned and discussed research results with unlimited energy and enthusiasm. He was obsessed by the idea that any method, tool, approach or therapy can be improved through precise observations and meticulous scientific work. Ehrlich had the capacities and academic insights to demonstrate that this is indeed the case - a virtue that may have contributed to the belief of many that this pioneering researcher was indeed a genius $[1-3,17,18]$.

Unfortunately, however, Paul Ehrlich's health was not robust and he smoked heavily. In 1888, Ehrlich's career 
Table 3. Historical overview of Paul Ehrlich's life and achievements

\begin{tabular}{|c|c|c|}
\hline Year(s) & Location & Life and career \\
\hline 1854 & Strehlen-Breslau & Birth \\
\hline 1878 & Charité Hospital Berlin & Development and evaluation of cell-specific dyes \\
\hline $1878-1887$ & Charité Hospital Berlin & $\begin{array}{l}\text { Delineation of various leukocytes based on their } \\
\text { dye-staining properties; foundation and birth of } \\
\text { modern hematology }\end{array}$ \\
\hline $1888-1889$ & Traveled to Egypt & Tuberculosis infection \\
\hline 1890 & Berlin & $\begin{array}{l}\text { Selectivity of methylene blue for the central nervous } \\
\text { system - studies of neuralgia }\end{array}$ \\
\hline $1891-1896$ & $\begin{array}{l}\text { Institute for Infectious } \\
\text { Diseases Berlin }\end{array}$ & $\begin{array}{l}\text { Methylene blue in } 2 \text { malaria patients; first attempt to } \\
\text { identify a 'magic bullet' } \\
\text { Standardization and large-scale production of therapeutic } \\
\text { antidiphtheria serum }\end{array}$ \\
\hline $1896-1899$ & Berlin & $\begin{array}{l}\text { Director of the Institute for Serum } \\
\text { Research and Evaluation }\end{array}$ \\
\hline 1897 & $\begin{array}{l}\text { Institute for Serum Research } \\
\text { and Evaluation Berlin }\end{array}$ & $\begin{array}{l}\text { Formulation of side-chain theory and the related concept of } \\
\text { cell-fixed and soluble antitoxins }\end{array}$ \\
\hline $1899-1906$ & Berlin & Director of the Royal Institute for Experimental Therapy \\
\hline 1900 & Berlin & Receptor-ligand concept \\
\hline 1903 & Berlin & Prussian Great Gold Medal for Science \\
\hline 1904 & Berlin & $\begin{array}{l}\text { Ehrlich and Shiga study trypanosomiasis in infected mice } \\
\text { and in vivo drug effects }\end{array}$ \\
\hline 1905 & $\begin{array}{l}\text { Royal Institute for Experimental } \\
\text { Therapy Frankfurt }\end{array}$ & $\begin{array}{l}\text { Structure of atoxyl and demonstration of the correlation } \\
\text { between its structure and its pharmacologic effect }\end{array}$ \\
\hline $1905-1907$ & Berlin and Frankfurt & Development of the concept of acquired drug resistance \\
\hline 1906 & $\begin{array}{l}\text { Frankfurt } \\
\text { Georg-Speyer-Haus (GSH) }\end{array}$ & $\begin{array}{l}\text { Director of GSH } \\
\text { Presentation of the concept of specific chemotherapy }\end{array}$ \\
\hline 1907 & Frankfurt (GSH) & $\begin{array}{l}\text { Synthesis of arsphenamine } \\
\text { Concept of chemoreceptor }\end{array}$ \\
\hline 1908 & & Nobel Prize \\
\hline 1909 & Frankfurt (GSH) & $\begin{array}{l}\text { Demonstrated the antispirochete activity of arsphenamine } \\
\text { (with Sahachiro Hata) }\end{array}$ \\
\hline 1914 & Frankfurt (GSH) & Synthesis of neoarsphenamine \\
\hline 1915 & Bad Homburg & Death \\
\hline
\end{tabular}

was disrupted when he was infected by the 'Koch bacillus', presumably during his laboratory work. As a consequence, Paul Ehrlich travelled to Egypt and Southern Europe with his wife, Hedwig, who married him in 1883 and with whom he had two daughters. After 2 years, Ehrlich recovered from pulmonary tuberculosis. He then returned to Berlin and continued his work, now focusing even more on immunology. Paul Ehrlich (fig. 1) often stated that to have success, one needed the 4 'Gs' (in German): Geld ('money'), Geduld ('patience'), Geschick ('skills') and Glück ('luck'). When being asked for the basis (reason) of his success with Salvarsan ${ }^{\circledR}$, he often replied: 'for 7 years of misfortune, I had one moment of luck'. In the wintertime of 1914, Paul Ehrlich survived a first stroke, and on August 20th, 1915, at the age of 61, he died after a second fatal stroke in Bad Homburg near Frankfurt, Germany.

\section{The Birth of Modern Hematology}

Paul Ehrlich was still a student when he established the principles of hematology by describing specific dye-staining properties of various leukocytes [10-13, 19]. Ehrlich applied alkaline-based and acid dyes, but had also developed novel neutral dye stains. Through applying such advanced dye-staining techniques and by comparing them with morphologic properties of various cells, Ehrlich was able to differentiate several distinct leukocyte subsets from each other and also from other cell types in various organs and tissues [10-13] (table 3). Paul Ehrlich also proposed terminologies for these cell types and, in almost all instances, the nomenclature was accurate and was soon accepted by the community - and in a slightly modified form the nomenclature is still in use today. Another out- 


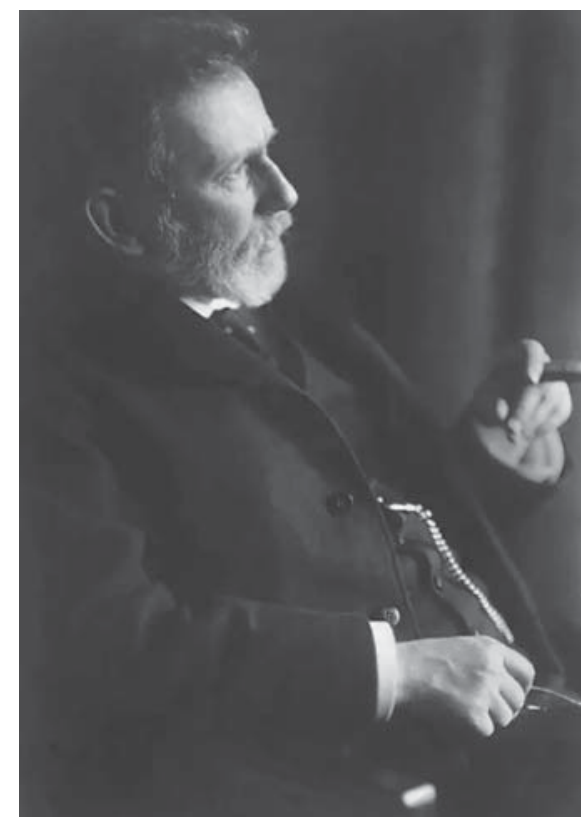

Fig. 1. Paul Ehrlich.

standing talent of Paul Ehrlich was his ability to recognize relationships between cell functions and morphologic cell features. For example, he linked distinct morphologies to certain maturation stages in hematopoietic lineages: from 1880, Ehrlich studied the red cell in detail and soon detected nucleated red cells in the blood and bone marrow. A few years later, he described putative maturation stages of red cell precursors, cells that he called 'normoblasts', 'megaloblasts', 'microblasts' and 'poikiloblasts' [20].

Although his research covered most hematopoietic cell systems, the favorite leukocyte of Paul Ehrlich was the mast cell [19]. This also highlights the fact that he did not only look into the blood with great dedication, but also into other organ systems. Although not formally established at that time, he proposed that blood leukocytes have the capacity of entering extravascular sites, an assumption that was supported by morphologic similarities between tissue mast cells and blood basophils. However, Paul Ehrlich remained skeptical about the origin of mast cells - and his skepticism was justified as, many decades later, mast cells were found to derive directly from hematopoietic precursor cells, but not from blood basophils, monocytes, macrophages or a local histiocyte. A relationship between mast cells and macrophages was a widely discussed hypothesis. Indeed, the term 'mast cell' (English: 'fed cell') points to the capacity of these cells to actively 'eat' extracellular material [20]. However, this assumption was incorrect as neutrophils and macro- phages, but not mast cells, specifically take up and digest bacteria and other microbes. The terminology applied to the other granulated types of leukocytes Paul Ehrlich proposed remained descriptive: eosinophils, basophils and neutrophils. All in all, Paul Ehrlich demonstrated that blood cells are much more heterogeneous cells than had been assumed previously, thereby paving the way to a new era of research and to modern hematology.

\section{Early Contributions to Microbiology and Laboratory Medicine}

In 1882, Robert Koch presented the discovery of the causal agents of tuberculosis, the mycobacterium, to the Society for Physiology in Berlin. The detection of these bacteria was again based on dye-staining reactions. Soon after Koch's presentation, Paul Ehrlich was able to improve the method of staining mycobacteria substantially and earned praise from Koch. The new method Ehrlich had introduced formed the basis of the Ziehl-Neelsen acid-fast staining reaction that was developed later and is still in use today [9]. Paul Ehrlich also contributed to the development of staining reactions through which other bacteria and microbes were detected and classified. For example, Ehrlich developed a precursor technique to the Gram staining of (Gram-positive) bacteria. However, Ehrlich also extended his interest to other diagnostic tests when working at the Charité Hospital in Berlin (18781887). For example, while still occupied with hospital duties at the Charité, Ehrlich developed the diazo reaction (Ehrlich's Diazo reagent) to detect urobilinogen (bilirubin) in the urine of jaundice patients [9]. Finally, Paul Ehrlich continued to develop optimized dye-staining reactions for the delineation of various tissue-fixed cells, bone marrow cells and blood leukocytes, thereby promoting modern pathology and hematology.

\section{Contributions to Applied Immunology and Antitoxin Research}

In 1890, Shibasaburo Kitasato and Emil Adolf von Behring described that the application of increasing doses of tetanus or diphtheria 'toxoids' to animals leads to the formation of antitoxins that can be transferred to secondary recipient animals for immunization purposes. This discovery induced a new era of vaccination medicine. However, this new discipline also raised important safety issues and led to the requirement for quality control during the pro- 
cess of antitoxin production. Robert Koch invited Paul Ehrlich to work with him and with von Behring on the standardization of the antidiphtheria serum production process at the Robert Koch Institute. Between 1890 and 1895, Ehrlich developed effective immunization protocols and the basis for large-scale production facilities. He proposed the use of horses for the commercial production of serum. In addition, he introduced standardization in the production processes $[9,15]$. In 1896, Ehrlich became the head of the Institute of Serum Research and Testing in Berlin. This institute was established to develop standardized preparations, to evaluate and quantify the effectiveness of antisera, and to explore the complex interactions between toxins and antitoxins. Later, this institute was relocated to Frankfurt, where Ehrlich was confirmed as director (table 3). In 1901, von Behring received the first Nobel Prize in Physiology or Medicine for his pioneering contribution to the development of serum therapy [16]. Although Ehrlich did not receive this first Nobel Prize himself, many believed that he had contributed substantially to van Behring's success and was already equally qualified in 1901.

\section{The Side-Chain Theory}

Ehrlich was fascinated by the idea of a specific immune reaction and its cellular and serologic (molecular) basis. In those days, the research community believed that distinct cells of the lymphoid (immune) system played a role in the production of antitoxins, and that some or even most of these antitoxins were specific in nature (toxin restricted). Ehrlich focused on the specific nature of these antitoxins (antibodies) and their production and release by certain immune cells. In 1897, Ehrlich formulated his 'side-chain theory', which soon became the basis of immunologic research (table 3). This theory postulated that certain cells expose a set of side-chains on their surface, and that these side-chains are associated with specific recognition [1-4, 21]. For example, a side-chain from a given cell might have a distinct molecular structure that allowed it to bind to a specific toxin, corresponding to diphtheria, tetanus or other microorganisms. The strictly specific binding between the toxin and the side-chain was explained by a theory similar to the 'lock-and-key model' for enzymes and their substrates described by Hermann Emil Fischer in 1894. The next step in this theory was that these side-chains may be released upon demand when toxins bind: '.. as the receptor is obviously pre-formed, and the produced antitoxin only a consequence (secondary), it seems reasonable to propose that the antitoxin is nothing else but discharged

Paul Ehrlich and the Birth of

Translational Medicine components of the cell, namely receptors discharged in excess ....' Toxin binding and antitoxin release would in turn trigger the production of additional side-chains, and these newly produced side-chains would again be released into the blood, where they would act as antitoxins upon binding to the toxin present in the blood, and would thus prevent the toxin from binding to other cells in the organism. Thus, a small amount of toxin could produce a large quantity of antitoxins able to neutralize the adverse toxin effect on normal cells $[4,21]$. Ehrlich also proposed that the soluble side-chains may assist in the elimination of microbes and, thus, aid in host defense. This was a fascinating hypothesis, and it was only a logical next step to propose that antitoxin-loaded cells can be eliminated effectively by the phagocytes and their 'eating machinery' Metchnikoff had described. In extension to the theory of soluble antitoxins (antibodies), Paul Ehrlich also established the concept of active and passive immunity, as well as the hypothesis that immunity can be transmitted from mothers to their fetuses [9]. All these ideas were fascinating and had been developed rapidly by Paul Ehrlich - and later proven to be correct - but were not always based on solid experimental evidence and were often difficult to understand. Therefore, Ehrlich was often criticized for his 'too lively' imagination and overinterpretation.

\section{From the Side-Chain Theory to a Receptor-Ligand Concept}

In 1900, Ehrlich had proposed the term 'receptor' to replace the original term 'receptive side-chain' (table 3 ). The new concept also implied that some of these binding sites were fixed but still mediated specific biological functions, and, more importantly, could serve as specific drug-binding sites. A similar concept had been proposed by John Newport Langley (1852-1925), who predicted that the effect of certain alkaloids on muscle cells were mediated by cell-fixed receptors that can be activated by agonists and blocked by specific antagonists. Together with Langley, Paul Ehrlich developed and extended his original receptor theory and proposed the existence of so-called 'chemoreceptors', binding sites that were specifically recognized by certain drugs and their derivatives or specific antagonists. This concept turned out to be correct and paved the way to modern pharmacology, advanced immunology and the development of targeting treatment concepts (table 2) [2123]. Two outstanding talents of Paul Ehrlich should be mentioned in this context of the development of a ligandreceptor concept - his flexibility to adjust and refine his 
own theories, and his ability to exploit collaborations and new achievements in other scientific disciplines in order to foster and extend his own concepts. Indeed, Ehrlich was always a superb 'networker' and open to new innovative theories and new important collaborations.

\section{The Concept of 'Magic Bullets' (Zauberkugeln)}

The next logical step was to extend the receptor-ligand concept and to exploit the specific effects of toxic agents with the aim of synthesizing and selecting those drugs that may kill certain microbes or other target cells but spare healthy tissues. Paul Ehrlich approached this concept in two consecutive steps: (i) by screening for toxic drugs and (ii) by modifying toxic drugs to be more specific and less toxic. First, Ehrlich established basic procedures for the chemical synthesis of various drugs and drug derivatives. The donation of Francisca Speyer to the Georg-SpeyerHaus and, thus, to Ehrlich was an essential basis of this work program. In fact, based on these donations, Ehrlich was able to establish a chemical laboratory where chemists and pharmacists synthesized a huge battery of chemical compounds. In the case of Salvarsan ${ }^{\circledR}$ it was compound 606. The head of the laboratory was Paul Karrer, and many patents of arsenic compounds carry his and Ehrlich's name. In a second step, Ehrlich screened pharmacological assays to evaluate and compare the efficacy of all these agents systematically. In many instances, the structure of an agent had to be modified in order to obtain a safe drug, or a new compound with a similar structure had to be generated. This systematic approach of drug development was a revolutionary concept and formed the basis of modern pharmacology [24-27]. It also paved the way to the concept of a 'magic bullet', a drug that would be completely specific for the target and therefore a safe agent because no additional toxic effects could occur. In the words of Paul Ehrlich [25]: ' $\ldots$ the optimal agent would combine high parasitotropism with low organotropism ....' Ehrlich also believed that experimental therapeutics should be tested in preclinical disease models, including animal models reflecting various pathologies, whereas, until that time, drug studies were largely restricted to studies of healthy animals or tissues. Although Paul Ehrlich was sure that his concept of a 'magic bullet' was generally applicable to all kinds of pathologies, the major area of his research remained infectious diseases. Later, Paul Ehrlich also tried to apply his 'magic bullet' concept to anticancer chemotherapy. In his days, the etiology of cancer remained essentially unknown and no cancer-specific structures (molecules) had been de- tected [28]. Many decades later, however, the seeds sown by Paul Ehrlich led to a new era of targeted anticancer therapies, including small molecule-type drugs directed against molecules responsible for malignant transformation, such as oncogenic kinases or antibody-based drugs directed against various cell surface structures expressed (more or less specifically) by neoplastic cells. These drugs can be regarded as Paul Ehrlich's 'Zauberkugeln' [29-31].

\section{From Drug Screening to the Development of Targeted Drugs}

The screening for 'magic bullets' had started in 1891, when Paul Ehrlich began to test the effects of methylene blue. Although he was able to treat malaria patients with some success, this therapy was not superior to the standard drug quinine. However, the example of methylene blue motivated Ehrlich and his colleagues to further screen for more effective agents. A next important success was the observation made by Paul Ehrlich and his coworker Kiyoshi Shiga (1871-1957) that trypan red was therapeutically effective in mice infected with Trypanosoma equinum (table 3 ). Unfortunately, however, the trypanosomes developed resistance. Nevertheless, this observation confirmed the principle value of the screen and provoked even more interest and greater efforts. As a next step, Ehrlich started to examine organic arsenic derivatives [32-35]. In 1905, his coworker Alfred Bertheim (1879-1914) deciphered the chemical structure of Atoxyl as an amino derivative of phenyl arsenic acid. This knowledge opened the door for modifying drug properties by artificially changing its chemical structure. Subsequently, a number of derivatives were synthesized with the aim of enhancing their therapeutic efficacy and of lowering their toxicity $[9,32-34]$. Finally, by adding substitutes to the amino group of Atoxyl, compound No. 306 (arsacetin) was designed. Unfortunately, this compound was strongly neurotoxic in mice and could not be developed further. However, Paul Ehrlich did not give up - he was convinced that chemical modifications would eventually lead to the development of a 'magic bullet'. Finally, a limited set of substances were developed. One of them, arsenophenylglycine (No. 418, Spirasyl ${ }^{\circledR}$ ) was found to be highly active against trypanosome and spirochete infections. In 1907, the drug was tested in humans with good results. However, severe hypersensitivity reactions occurred in a subset of patients. Subsequently, the drug was only used to treat patients with severe life-threatening trypanosomiases. The next promising drug Paul Ehrlich developed was 
arsenophenol, a highly effective agent against trypanosomes. Unfortunately, based on instability and difficulties to purify the drug, its development had to be stopped. Nevertheless, a similar agent was produced by adding a substituent next to the hydroxyl group, compound No. 606 , also known as arsphenamine or diaminodioxyarsenobenzol. This compound was synthesized in 1907. However, in a first series of experiments no consistent antimicrobial activity could be demonstrated, and it took until 1909 before reassessment of the drug and its pharmacologic activity paved the way to the successful treatment of syphilis.

\section{Successful Translation - The Case of Salvarsan}

After a long road of development, many years of hard work and investment, and many days of disappointment and frustration, Ehrlich had this 'one day of good luck' when he and his coworkers successfully produced their long desired first synthetic 'magic bullet'. It was a late triumph, but it was a triumph of science and of the visions and theories Ehrlich had propagated, namely that: (i) the chemical structure of a compound would correlate with specific activity, (ii) drug efficacy can be improved by proper chemical modification and (iii) toxicity can be kept under control by creating a magic bullet (targeted drug). Paul Ehrlich had demonstrated that synthesis of specific drugs is achievable. This visionary attitude and his practical abilities to translate these concepts into practical application (in patients) are the reasons he is considered such an outstanding figure in medical science.

In 1905, Fritz Schaudinn (1871-1906) and Erich Hoffmann (1868-1959) described Treponema pallidum as a causal agent of syphilis. In those days the impact of syphilis on society was comparable to that of AIDS today. Based on the similarities between spirochetes and trypanosomes, Hoffmann suggested to Ehrlich the idea of applying arsenical compounds to patients with syphilis. As a result, Paul Ehrlich's co-worker Sahachiro Hata (1873-1938) reassessed all the arsenicals synthesized until then, and found that compound No. 606 had a major curative potential in rabbits infected with T. pallidum, without producing intolerable toxicity (table 3 ). Thus, they had discovered a magic bullet to treat syphilis: arsphenamine (Salvarsan ${ }^{\circledR}$ ) [36-38].

However, based on the severe hypersensitivity reactions documented in patients receiving arsenophenylglycine, arsphenamine was developed with great caution. Only after a very careful testing in a larger series of ani- mal experiments that confirmed its safety, their 'magic bullet' was administered to patients. On the 19th of April, 1910, at the Congress for Internal Medicine at Wiesbaden, Hata and Ehrlich presented their results obtained with arsphenamine $[39,40]$. Their announcement at this meeting provoked a huge number of requests, and Ehrlich's institute had to prepare and dispense 65,000 samples immediately to be forwarded to various hospitals and centers that had initiated clinical trials. Based on further demand worldwide, the Hoechst company took over and distributed the drug under the name Salvarsan ${ }^{\circledR}$, 'the arsenic that saves'. Ehrlich's international recognition and popularity increased with the success story of Salvarsan.

\section{Post-Salvarsan Development}

Over the years it turned out that treatment with Salvarsan was not perfect, as resistance occurred and combination therapy with mercury or bismuth treatment was often necessary to eliminate all spirochetes. The minimum period of treatment with Salvarsan lasted for 18 months and required 20 Salvarsan injections and 30-40 bismuth injections [41]. Problems also arose from the galenics of the arsphenamide preparations, mostly because of the water-insoluble nature of the drug.

In 1914, the year of Paul Ehrlich's 60th birthday, compound No. 914 (neoarsphenamine) was developed [33] and soon distributed on the market as Neosalvarsan ${ }^{\circledR}$ (table 3). This second-generation drug improved overall outcomes and shortened the treatment time of patients with syphilis. However, although it was less toxic compared to Salvarsan ${ }^{\circledR}$, Neosalvarsan ${ }^{\circledR}$ still produced several relevant adverse effects, such as nausea or vomiting. An additional problem was that Salvarsan ${ }^{\circledR}$ and Neosalvarsan ${ }^{\circledR}$ had to be stored in sealed vials under a nitrogen atmosphere to prevent oxidation.

In 1930, the oxidation product of arsphenamine was recognized as an active metabolite and was subsequently developed as a new drug, named oxophenarsine (Mapharsen ${ }^{\circledR}$ ). Based on its stability, this agent became the drug of choice for the treatment of syphilis until penicillin was introduced in the early 1940s. It is noteworthy that oxophenarsine had already been synthesized in Paul Ehrlich's laboratory (compound No. 599), but was considered to be too toxic and therefore was not further developed. 


\section{Concluding Remarks}

Paul Ehrlich's contributions to science undoubtedly paved the way to a new era of medicine, where cellular features and functions were linked to specific molecules, and translational concepts were established based on mechanistic and molecular insights into the pathophysiology of the disease and specific molecular interactions, including drug-target and receptor-ligand interactions. The seminal contributions of Paul Ehrlich and his colleagues also led to the birth and foundation of modern chemistry, hematology, immunology, chemotherapy, pharmacology and oncology. Finally, the concept of specific drug development and global standardization of diagnostic and therapeutic approaches are based on the seminal work of Paul Ehrlich and his colleagues.

\section{References}

1 Lapage G: Paul Ehrlich. Nature 1952;169:362.

2 Drews J: Paul Ehrlich: magister mundi. Nat Rev Drug Discov 2004;3:797-801.

3 Paul-Ehrlich-Institut: Gesamtliste der Publikationen von Paul-Ehrlich. http://www.pei. de/DE/institut/paul-ehrlich/publikationengesamtliste-paul-ehrlich/publikationengesamtliste-paul-ehrlich-node.html.

4 Ehrlich P: Die Seitenkettentheorie und ihre Gegner. Münchner Med Wochenschr 1901: 2123-2124.

5 Ehrlich P: Anwendung und Wirkung von Salvarsan. Dtsch Med Wochenschr 1910:24372438.

6 Piro A, Tagarelli A, Tagarelli G, Lagonia P, Quattrone A: Paul Ehrlich: the Nobel Prize in physiology or medicine 1908. Int Rev Immunol 2008;27:1-17.

7 Kaufmann SH: Immunology's foundation: the 100-year anniversary of the Nobel Prize to Paul Ehrlich and Elie Metchnikoff. Nat Immunol 2008;9:705-712.

8 Schmalstieg FC Jr, Goldman AS: Ilya Ilich Metchnikoff (1845-1915) and Paul Ehrlich (1854-1915): the centennial of the 1908 Nobel Prize in Physiology or Medicine. J Med Biogr 2008;16:96-103.

9 Boscha F, Rosich L: The contributions of Paul Ehrlich to pharmacology: a tribute on the occasion of the centenary of his Nobel Prize. Pharmacology 2008;82:171-179.

10 Buchwalow I, Boecker W, Tiemann M: The contribution of Paul Ehrlich to histochemistry: a tribute on the occasion of the centenary of his death. Virchows Arch 2015;466:111116.

11 Ehrlich P: Beiträge zur Kenntnis der Anilinfärbungen und ihrer Verwendung in der mikroskopischen Technik. Arch Mikrosk Anat 1877;13:263-278.

12 Ehrlich P: Ueber die specifischen Granulationen des Blutes. Arch Anat Physiol Physiol Abt 1879:571-579.

13 Ehrlich P: Beiträge zur Kenntniss der granulirten Bindegewebszellen und der eosinophilen Leukocythen. Arch Anat Physiol Physiol Abt 1879:166-169.
14 Sörgel F, Landersdorfer C, Holzgrabe U: Welche Berufsbezeichnung wird Ehrlichs Wirken gerecht? Bemerkungen zu seinem 150. Geburtstag. Chemotherapie J 2004;13: 157-165.

15 Ehrlich P: Die Wertbemessung des Diphterieheilserums und deren theoretische Grundlagen. Klin Jahrbuch 1897;6:299-326.

16 Nobelprize.org: Official Web Site of the Nobel Prize. Stockholm, 2008. http://nobelprize.org (accessed May 5, 2008).

17 Sörgel F, Landersdorfer C, Bulitta J, Keppler B: Vom Farbstoff zum Rezeptor: Paul Ehrlich und die Chemie. Nachrichten Chem 2004: 52777-52782.

18 Hüntelmann AC: Paul Ehrlich: Leben, Forschung, Ökonomien, Netzwerke. Göttingen, Wallstein, 2011.

19 Crivellato E, Beltrami CA, Mallardi F, Ribatti D: Paul Ehrlich's doctoral thesis: a milestone in the study of mast cells. Br J Haematol 2003; 123:19-21.

20 Ehrlich P: Ueber einen Fall von Anämie mit Bemerkungen über regenerative Veränderungen des Knochenmarks. Charité-Ann 1888; 13:300-309.

21 Kasten FH: Paul Ehrlich: pathfinder in cell biology. 1. Chronicle of his life and accomplishments in immunology, cancer research, and chemotherapy. Biotech Histochem 1996;71: 2-37.

22 Kristiansen JE: Dyes, antipsychotic drugs, and antimicrobial activity. Fragments of a development, with special reference to the influence of Paul Ehrlich. Dan Med Bull 1989;36: 178-185.

23 Bennett MR: The concept of transmitter receptors: 100 years on. Neuropharmacology 2000;39:523-546.

24 Parascandola J: The theoretical basis of Paul Ehrlich's chemotherapy. J Hist Med Allied Sci 1981;36:19-43.

25 Witkop B: Paul Ehrlich and his magic bullets - revisited. Proc Am Philos Soc 1999;143: 540-557.

26 Winau F, Westphal O, Winau R: Paul Ehrlich - in search of the magic bullet. Microbes Infect 2004;6:786-789.

27 Schwartz RS: Paul Ehrlich's magic bullets. N Engl J Med 2004;350:1079-1080.
28 Ehrlich P: Referat über die Genese des Carcinoms. Verh Dtsch Pathol Ges 1908;12:13-32.

29 Drews J: Case histories, magic bullets and the state of drug discovery. Nat Rev Drug Discov 2006;5:635-640.

30 Sanz L, Blanco B, Alvarez-Vallina L: Antibodies and gene therapy: teaching old 'magic bullets' new tricks. Trends Immunol 2004;25: 85-91.

31 Newsome BW, Ernstoff MS: The clinical pharmacology of therapeutic monoclonal antibodies in the treatment of malignancy; have the magic bullets arrived? Br J Clin Pharmacol 2008;66:6-19.

32 Cowley AH, Lasch JG, Norman NC, Pakulski M: Synthesis and structure of a diarsene: the first compound with an unsupported arsenicarsenic double bond. J Am Chem Soc 1983; 105:5506-5507.

33 Jolliffe DM: A history of the use of arsenicals in man. J R Soc Med 1993;86:287-289.

34 Rubin RP: A brief history of great discoveries in pharmacology: in celebration of the centennial anniversary of the founding of the American Society of Pharmacology and Experimental Therapeutics. Pharmacol Rev 2007;59:289-359.

35 Kaufmann SHE: Paul Ehrlich: founder of chemotherapy. Nat Rev Drug Discov 2008;7:373.

36 Krantz JC Jr: Historical Medical Classics Involving New Drugs. Paul Ehrlich and 'The Magic Bullet', Arsphenamine. Baltimore, Williams and Wilkins, 1974, pp 51-57.

37 Riethmiller S: From atoxyl to Salvarsan: searching for the magic bullet. Chemotherapy 2005;51:234-242.

38 Lloyd NC, Morgan H, Nicholson BK, Ronimus RS: The composition of Ehrlich's salvarsan: resolution of a century-old debate. Angew Chem Int Ed Engl 2005;44:941-944.

39 Sneader W: Drug Discovery: A History. Chichester, Wiley, 2005.

40 Gensini GF, Conti AA, Lippi D: The contributions of Paul Ehrlich to infectious disease. J Infect 2007;54:221-224.

41 Marlow FW: Syphilis then and now. JAMA 1974;230:1320-1321. 